\title{
The Mitotic Index of Cajanus cajan from Kisar Island, in the Southwest of Maluku
}

\author{
Kristin Sangur, Alwi Smith", Meike Tomasoa \\ Biology Education Study Program, Faculty of Teacher Training and Education, Universitas Pattimura, Indonesia \\ *Corresponding Author: smith.alwi2020@gmail.com
}

Submitted: 2021-03-16. Revised: 2021-05-29. Accepted: 2021-07-24

\begin{abstract}
The mitotic index of the roots of pigeon pea can be the basis for determining the growth of pigeon pea. The purpose of this research was to determine the time of root cell division, to observe the mitotic phases, and to determine the mitotic index of pigeon pea root cells. The preparation of the pigeon pea was carried out for 4 days to grow the roots. The roots were cut off at 08.00 , 08.15 , and 08.30 WIT (Eastern Indonesian Time). The roots were cut $0.5-1 \mathrm{~cm}$. Carnoy's solution was used as the fixative solution using the Squash technique. The prepared roots were then observed using an Olympus cx-22 microscope and an OptiLab camera with a magnification of $100 \times 40$. The data were descriptively analyzed to describe the images of mitotic phases and the mitotic index presentation in the root cells of pigeon pea. The results of this research showed that the cell division of the pigeon pea roots began at 08.00 WIT, which was marked by the presence of a lot of prophase. The next phases that appeared were prometaphase, metaphase, and anaphase which occurred from 08.15 to 08.30 with different numbers. The highest mitotic index occurred at 08.15 , when most of the root cells underwent metaphase. This study succeeded in revealing that the optimum time for pigeon pea root cell division is 08.15 WIT. In the future, this research can help pigeon pea farmers in Southwest of Maluku to carry out vegetative reproduction which is closely related to this mitotic study.
\end{abstract}

Key words: Cajanus cajan; mitotic index; pigeon pea; Southwest Maluku

How to Cite: Sangur, K., Smith, A., \& Tomasoa, M. (2021). The Mitotic Index of Cajanus cajan from Kisar Island, in the Southwest of Maluku. Biosaintifika: Journal of Biology \& Biology Education, 13(2), 128-134.

DOI: http://dx.doi.org/10.15294/biosaintifika.v13i2.29496

\section{INTRODUCTION}

Pigeon pea (Cajanus cajan) is one of the biodiversity of legumes from Kisar Island, Southwest Maluku, in addition to peanuts, red kidney beans, green beans, and cowpeas. The seeds of the pigeon pea are round or lens-shaped, the color of the seed coat varies from dirty white to silver white, light brown to brown, speckled with dark brown and dark pink, and yellow cotyledons (Saxena et al., 2010). The term pigeon pea appeared in the $15^{\text {th }}$ century, originating from America because the seeds were favored by pigeons (Upadhyaya et al., 2015). Nowadays this plant is only consumed as a vegetable and used as a side crop, when compared to other types of plants grown by the people on Kisar Island. In fact, pigeon pea has several superior characteristics to be studied and further developed, so that it can be more optimally used. Pigeon pea contains several nutrients such as $20-22 \%$ protein, $1.2-4.43 \%$ fat, $65 \%$ carbohydrates, $7.16 \%$ fiber, and $3.76-3.80 \%$ ash (Sharma et al., 2011; Akande et al., 2010). In addition, it also contains several kinds of vitamins such as thiamine, riboflavin, and niacin; minerals such as potassium, phosphorus, iron and zinc, calcium, manganese, and copper (Adepoju et al., 2019). The pigeon pea is more tolerant of drought and high temperatures than other types of legume. It has woody and sturdy trees and taproots that grow fast and deep (Flower \& Ludlow, 1987; Mathew et al., 2015). Mligo and Craufurd (2005) also added that the flowering characteristic of polycarpic pigeon pea is a way to respond to high environmental stress. The research by Deeplanaiki et al. (2013) reported that the cultivar pigeon pea Asha (ICPL 87119) has a DLP gene that determines its function in environmental stress tolerance.

To optimize the use of pigeon pea, genetic improvement can be done as an effort to improve plant quality, namely through chromosome manipulation (Khoiroh et al., 2015). According to Corneillie et al. (2019), the indirect use of genetic information in plant breeding is in the form of increasing knowledge of the genetic makeup of a particular type of plant, and the direct use of genetic information in plant breeding is in the form of applying cytogenetic techniques to improve plant traits. Chromosomes are nucleoprotein structures, carrying genetic material in the form of DNA as a unit of heredity and carrying information for cell regulatory activity (Crow \& Crow, 2002; Francis, 2007). The main function of chromosomes is to be responsible for separating the same amount of DNA and ensuring that the offspring carries the traits of both parents at each cell division (Bass \& Birchler, 2011). 
The first step in studying chromosomes is to observe the phases of mitosis. Mitosis is the process of genome division that has been duplicated by a cell into two identical cells produced by cell division. Mitosis consists of five phases, namely prophase, prometaphase, metaphase, anaphase, and telophase (Muhlisyah et al., 2014; Sharma \& Vig, 2012). It is essential that mitosis research be conducted in order to obtain the best cell phase, which is when the chromosomes are clearly visible and scattered, so that they can be easily counted. Chromosomes can be well observed when the cells are in the late prophase stage (El-Ghamery et al., 2000). The mitotic phase is closely related to the time of cell division in these plants. The research by Raja et al. (2015) reported that the time for cell division of Capsicum annuum was between 06.00 and 08.15 o'clock. The research by Abidin (2014) showed that the most active mitotic activity in the genus Allium varies such as the mitotic activity in A. sativum and A. fistulosum occurs in the morning at 09.00 and 06.00 WIB (Western Indonesian Time), while the mitotic activity in $A$. cepa occurs at noon at $12.00 \mathrm{WIB}$. The research by Willie and Aikpokpodion (2015) showed that the most active mitotic division in Vigna unguiculata occurs at 07.00-14.00, with the peak occurring at 11.00-13.00. This shows that the time for cell division of each plant is different and not constant. Another contributing factor is the time of cutting the roots.

Meanwhile, some information related to cell division, including the time of cell division, characterization of the mitotic phase, the number of cells undergoing mitosis, and the mitotic index of pigeon pea root cells from the Kisar island of Southwest Maluku has not been carried out. In fact, the calculation of cells undergoing mitosis can be the basis for determining the magnitude of the mitotic index of these pigeon pea root cells. Tabur and Oney (2009) reported that the mitotic index value increases when there is an increase in cell division. The mitotic index is the ratio of the number of cells that undergo mitosis in each phase (Rossato et al., 2010). Abidin (2014) also added that the mitotic index is an indicator of growth, where the greater the mitotic index, the better the plants grow. Therefore, determining the time of cell division and observing the mitotic phase of pigeon pea root cells are very essential, in order that the calculation of the mitotic index of pigeon pea root cells can also be done. The purpose of this research was to determine the time of root cell division, to observe the mitotic phases, and to determine the mitotic index of pigeon pea root cells (C. cajan). This research reveals that scientific information about the optimum time for pigeon pea cell division so as to help farmers in Southwest of Maluku in vegetative reproduction.

\section{METHODS}

\section{Sample preparation}

The seeds of Pigeon pea (C. cajan) used were black seeds from North Romleher Hamlet, Wonreli village, Kisar island, Southwest Maluku regency (Figure 1). This research began with soaking the pigeon pea seeds for 12 hours, and then the pigeon pea seeds were sprouted for 4 days. The root cutting was carried out at 08.00, 08.15, and 08.30 WIT (Eastern Indonesian Time). The roots were cut $0.5-1$ $\mathrm{cm}$. The cut roots were then put in a flacon bottle and then pre-treated by soaking the roots in distilled water for 24 hours. The roots were then fixed with $2 \mathrm{ml}$ of Carnoy's solution at room temperature for 24 hours, after which the roots were washed using distilled water. The roots were then hydrolyzed with $2 \mathrm{ml}$ of $\mathrm{HCl} 1 \mathrm{~N}$ solution in an oven at $60^{\circ} \mathrm{C}$ for 30 minutes. After that, the roots were washed using distilled water again. The roots were stained using $2 \mathrm{ml}$ of aceto orcein $2 \%$ and soaked for 30 minutes at room temperature (Setiawan et al., 2018).

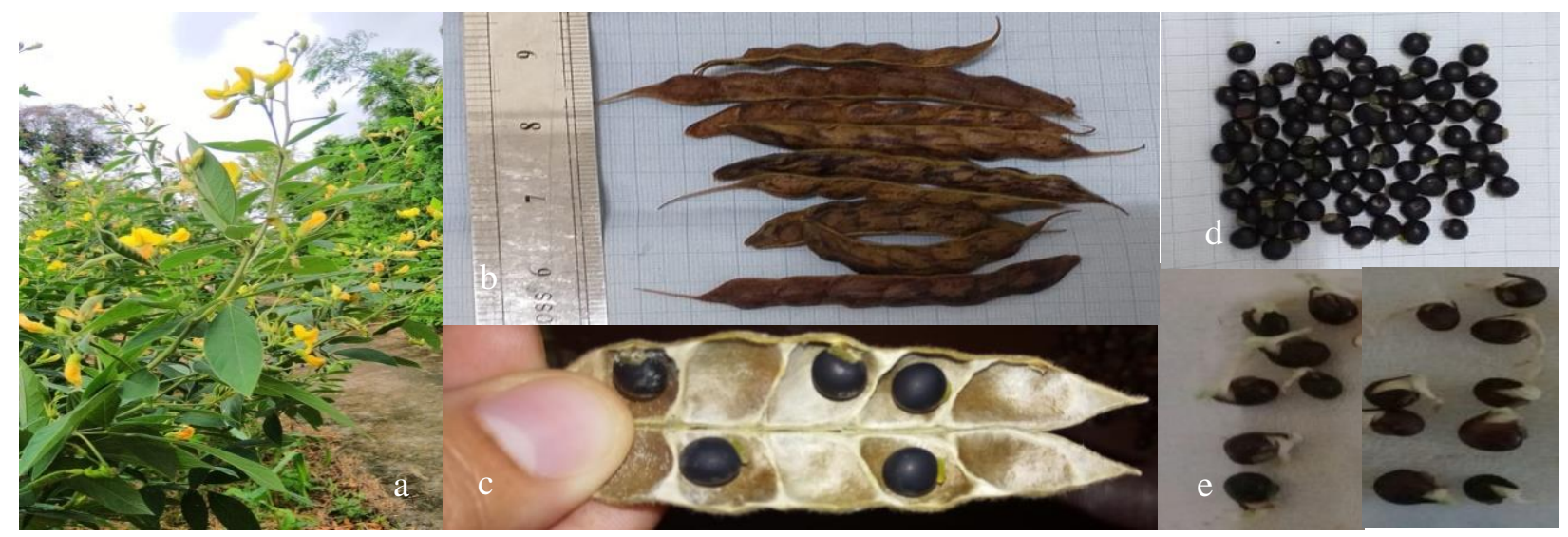

Figure 1. Pigeon pea (C. cajan) plant. (a) Flowering plants; (b) Pigeon pea pods; (c) Appearance of pigeon pea seeds in pods; (d) Black pigeon pea seeds; (e) Sprouted pigeon pea seeds. 


\section{Root cell observation}

The preparation was carried out using the Squash method. The prepared roots were then observed using an Olympus CX-22 microscope and an OptiLab camera with a magnification of $100 x 40$. The data of the cleavage of each mitotic phase were then observed, calculated, and recorded.

\section{Calculation of the mitotic index}

The mitotic index was calculated using the formula following Darbelley et al. (1989), namely: $I M=\frac{N m}{N} \times 100 \%$

Description:

$\mathrm{IM}=$ Mitotic Index

$\mathrm{Nm}=$ Number of cells undergoing mitosis from prophase to telophase in one mitotic preparation

$\mathrm{N}=$ Number of all cells observed

\section{Data analysis}

The data were descriptively analyzed to describe the images of mitotic phases and the presentation of the mitotic index of the pigeon pea root cells.

\section{RESULTS AND DISCUSSION}

Every plant has its own biological clock for mitotic division. The cutting time is a crucial stage because it can affect cell division (Etikawati \& Setyawan, 2000). In addition, the cutting time also affects the duration of mitosis and the mitotic index (Yadav, 2007). In the previous research, the roots of Allium sativum were cut at 08.00 WIB (Western Indonesian Time) (Setyawan \& Sutikno, 2000), while the roots of A. ascalonicum L. were cut at $09.00 \mathrm{WIB}$ (Western Indonesian Time) (Abdullah et al., 2017). In addition, Iriani et al. (2020) in their research reported that the leaflets of Hibiscus rosa-sinensis (L.) were cut at 08.00 WIB (Western Indonesian Time). Based on the results of this research, the mitosis of the root cells of pigeon pea (C. Cajan) began at the time of the root cutting at 08.00 WIT (Eastern Indonesian Time).

Table 1. Images of the prepared pigeon pea roots (C. cajan) based on differences in cutting time

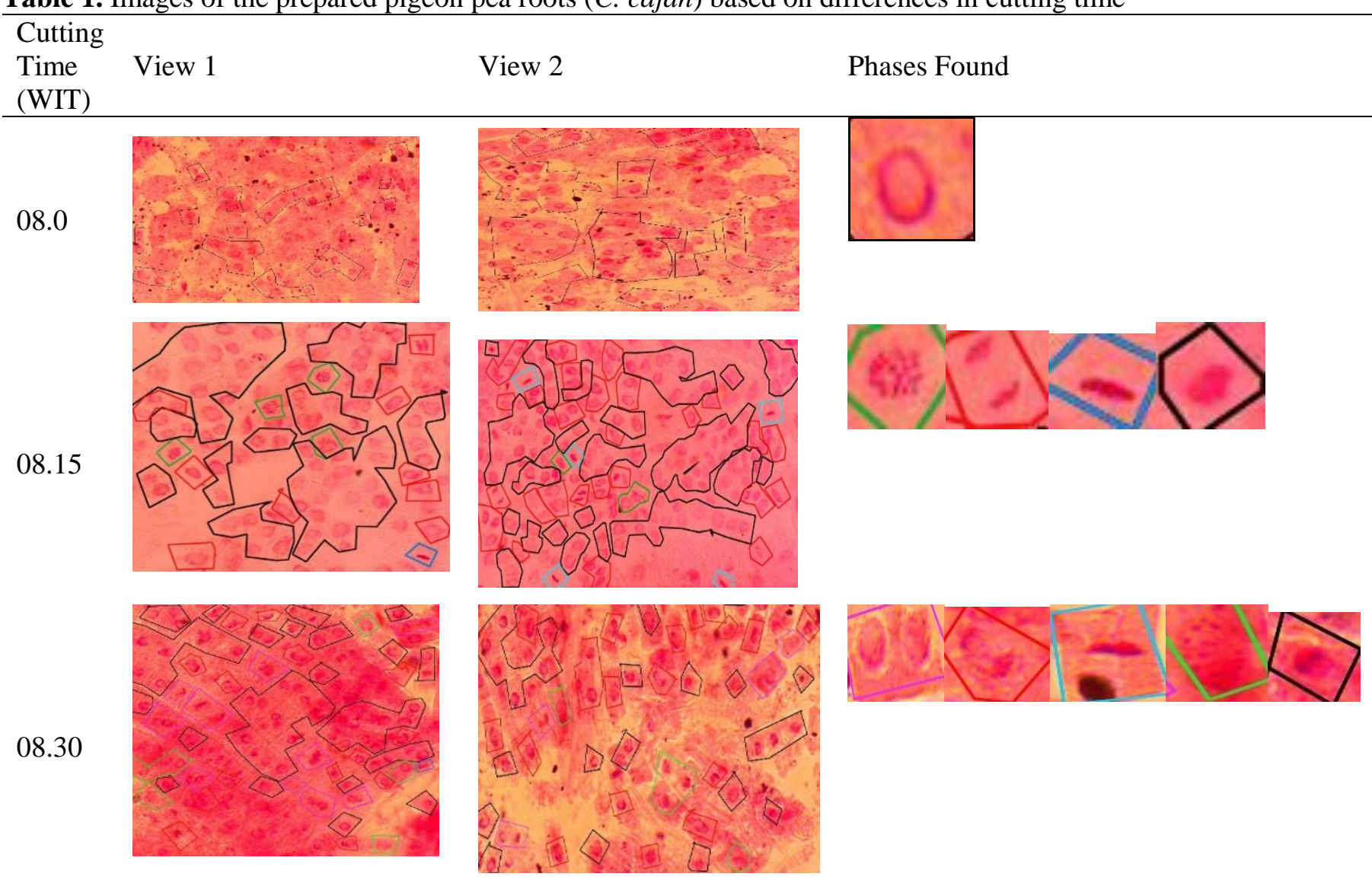

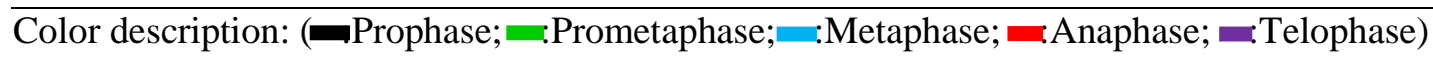


The prophase in the mitotic division of pigeon pea root cells started at 08.00 , and even the prophase continued until 08.30 (Table 1). According to Zoller et al. (2004), the prophase stage in mitotic division is characterized by the chromosomes condensing linearly, shortening, and increasing in diameter. The results of the observation showed that both prometaphase and metaphase appeared at the cutting time from 08.15-08.30. Prometaphase is the final stage of prophase and the beginning of metaphase. The metaphase stage is characterized by the chromosomes being scattered into strands and having a longer chromosome size and clearly observed chromosome structure. The research by Yuniastuti et al. (2021) reported that the optimal time for pigeon pea root cell division is at 08.15 o'clock, when the metaphase is occurring. The same result was also found in this study that the root tip of pigeon pea from Kisar Island had a metaphase time of 08.15.

This is characterized with the chromosomes being evenly spread, and the length can be easily observed. Furthermore, Wanjari et al. (2016) explained that at the time of metaphase, the chromosomes were in a condensed condition, so that they provided detailed information regarding the optimal chromomeric pattern and size. The metaphase stage is also characterized by the formation of spindle thread. The spindle thread plays a role in the separation of chromosomes, where metaphase is characterized by the alignment of chromosomes in the cell equator plane (Hartl \& Jones, 2005). Whereas at the anaphase stage, the chromosomes begin to separate and the chromatids will go to the poles of the cell. The anaphase and telophase were also found during the division of pigeon pea root cells at 08.15-08.30. The migration of the two sets of daughter chromosomes that move to opposite poles indicates that the anaphase process has been completed and the two daughter cells have the same number of chromosomes (Enger et al., 2012). The final stage of the mitotic phase is telophase. According to Elrod and Stansfield (2002), in the telophase phase, each separate chromatid set converges at the two poles of the cell and these chromatids now turn into chromosomes.

Further analysis was carried out to determine the number of cells undergoing mitotic division from each phase. The number of cells undergoing different phases of mitosis at each root cutting time can be seen in Table 2.

Table 2. The number of mitotic phases of pigeon pea (C. cajan) based on the difference of cutting time

\begin{tabular}{|c|c|c|c|c|c|c|}
\hline \multirow{2}{*}{ Time } & \multirow{2}{*}{ View } & \multicolumn{5}{|c|}{ Mitotic Phases } \\
\hline & & Prophase & Prometaphase & Metaphase & Anaphase & Telophase \\
\hline \multirow{2}{*}{08.00} & I & 33 & & & & \\
\hline & II & 48 & & & & \\
\hline \multicolumn{2}{|c|}{ Average \pm Standard deviation } & $40.5 \pm 10.61$ & & & & \\
\hline \multirow{2}{*}{08.15} & I & 73 & 4 & 1 & 11 & \\
\hline & II & 113 & 2 & 5 & 48 & \\
\hline \multicolumn{2}{|c|}{ Average \pm Standard deviation } & $93 \pm 28.28$ & $3 \pm 1.41$ & $3 \pm 2.83$ & $29.5 \pm 26.16$ & \\
\hline \multirow{3}{*}{$\begin{array}{l}08.30 \\
\text { Avera }\end{array}$} & I & 51 & 7 & 1 & 14 & 10 \\
\hline & II & 24 & 5 & 0 & 19 & 4 \\
\hline & deviation & $37.5 \pm 19.09$ & $6 \pm 1.41$ & $0.5 \pm 0.71$ & $16.5 \pm 3.54$ & $7 \pm 4.24$ \\
\hline
\end{tabular}

Prophase was found at any cutting time in both types of fixative solutions and had a very large and dominant amount when compared to the other mitotic phases. This shows that the root division time of pigeon pea originating from Southwest Maluku has a long cell division time starting from 08.00-08.30. This is in accordance with the research results by Kusumaningrum et al. (2012) that prophase is a long phase among other phases, this is indicated by the chromatin threads that experience spinning and thickening to form chromosomes, then in the middle of prophase the chromosomes are seen as two chromatids that are bound by the centromere until the final prophase where the cell nucleus is degraded. Moreover, Cooper (2000) stated that prophase takes the longest time compared to the other stages in the mitotic phase, which is the half time of one whole mitotic phase.

Prometaphase is a phase of mitosis following prophase, so that this phase was not found at the 08.00 cutting time, but it was found at the 08.15 cutting time. This shows that the time for cell division of pigeon pea roots began at 08.00 , indicated by the appearance of prophase. Previous research on prometaphase in several other plants has reported that the highest prometaphase in the roots of Passiflora edulis was found at 10.20 after prophase (Muhlisyah et al., 2014). Rindyastuti and Daryono (2009) found that the highest prometaphase in Coccinia grandis species was at 09.50-10.15 after prophase, while the prometaphase in lime and kaffir lime was found 
mostly at 08.00 WIB (Western Indonesian Time) after prophase (Arisuryanti et al., 2007).

Metaphase and anaphase were only found at the cutting time of 08.15-08.30 WIT (Eastern Indonesian Time), while telophase was only found at the cutting time of 08.30 WIT (Eastern Indonesian Time). When compared with the number of prophase, the number of the other three phases (metaphase, anaphase, and telophase) was fewer (Table 2). This may happen because the three phases tended to have short duration. Anaphase is a short-time stage which includes the separation of sister chromatids, and morphological changes in the inner cytoskeleton of cells which include astral microtubules as the main driver of spindle elongation, while spindle middle zone microtubules hold or regulate the rate of polar separation. The results of the same study were also presented by Rosculete et al. (2019) that the percentage of prophase remains higher than the percentage of metaphase, anaphase, and telophase despite exposure to herbicides. In addition, Ito et al. (2001) reported the percentage of all phases of mitosis in tobacco root tip cells, which was prophase $11 \%$, metaphase $2 \%$, anaphase and telophase $1 \%$. Some of this research could corroborate the finding that pigeon pea $(C$. cajan) has a percentage of prophase higher than the other phases of mitosis.

Table 3. Mitotic index of pigeon pea root (C. cajan) based on the difference in the cutting time

\begin{tabular}{ccccc}
\hline $\begin{array}{c}\text { Cutting Time } \\
(\text { WIT })\end{array}$ & $\begin{array}{c}\text { Number of Cells } \\
\text { Observed }\end{array}$ & $\begin{array}{c}\text { Number of Cells Undergoing } \\
\text { Mitosis at Each View }\end{array}$ & $\begin{array}{c}\text { Mitotic Index of Pigeon pea } \\
\text { Roots (C.cajan) (\%) }\end{array}$ \\
\hline \multirow{2}{*}{08.00} & 41 & View I & 33 & 80.49 \\
& 53 & View II & 48 & 90.57 \\
08.15 & Average \pm Standard & deviation & & $85.53 \pm 7.13$ \\
& 100 & View I & 89 & 89 \\
& 180 & View II & 168 & 93.33 \\
08.30 & Average \pm Standard & deviation & & $91.17 \pm 3.06$ \\
& 92 & View I & 83 & 90.22 \\
& 62 & View II & 52 & 83.87 \\
\hline
\end{tabular}

The mitotic index is a comparison of the number of cells undergoing mitosis with the total number of cells in an observation. Based on the percentage of the mitotic phases of pigeon pea, it shows that the highest mitotic index value is when the percentage of metaphase increases at 08.15 WIT (Table 3). This is in accordance with the research results conducted by Osuji and Owei (2010), who examined the mitotic index of Treculia africana, and the research by Adesoye \& Nnadi (2011), who examined the mitotic index of Sphenostylis stenocarpha (Hochst. Ex. A. Rich.). Both of the research concluded that the highest mitotic index occurred during the high percentage of cell metaphase. Moreover, Ekanem and Osuji (2006) explained that the highest mitotic index is in the metaphase phase, such as what was found in the Caladium varieties. Shervani and Mishra (2020) stated that different conditions may affect the mitotic index in the root tips of Tinospora cordifolia. Similarly, it is also indicated that different cutting time causes differences in the mitotic index. This research revealed that the cutting time of pigeon pea root cells (C. cajan) from Southwest of Maluku was at 08.15 WIT with the highest mitotic index. This research is a basic research to be a reference for the analysis of the mitotic index of other pigeon pea varieties in Southwest of Maluku. In addition, the research results can be used as scientific information for vegetative reproduction of pigeon pea.

\section{CONCLUSION}

The results of observations and analysis of the mitotic index of Pigeon pea root cells (C. cajan) show that the cell division began at 08.00 WIT (Eastern Indonesian Time), marked with the appearance of prophase. The cell division continued until 08.30 WIT, which was marked with the appearance of telophase. The highest mitotic index occurred at 08.15 WIT, which corresponded to the high number of root cells undergoing metaphase.

\section{ACKNOWLEDGEMENT}

Researchers would like gratitude to the Dean of the Faculty of Teacher Training and Education, Pattimura University, Ambon for funding this research grant with number SK.64 / UN13.1.3 / SK / 2019.

\section{REFERENCES}

Abdullah, F., Ady, S. \& Widayat. (2017). Penentuan waktu perendaman sel (fase mitosis) Akar 
Bawang Merah (Allium ascalonicum L.) menggunakan safranin untuk mendukung praktikum biologi [Determining the soaking time of cells (mitotic phases) of shallot roots Allium ascalonicum L. using safranin to. Bioleuser, 1(3), 86-89.

Abidin, A. (2014). Studi indeks mitosis bawang untuk pembuatan media pembelajaran preparat mitosis [The study of the mitotic index of onion to develop mitosis learning media]. Berkala Ilmiah Pendidikan Biologi, 3(3), 571-579.

Adepoju, O., Dudulewa, B. \& Bamigboye, A. (2019). Effect of cooking methods on time and nutrient retention of pigeon pea (Cajanus cajan). African Journal of Food, Agriculture, Nutrition and Development, 19(3), 14708-14725.

Adesoye, A. \& Nnadi, N. (2011). Mitotic chromosomes studies of some accessions of African Yam Bean, Sphenostylis sternocarpa (Hochst. ex. A. Rich.) Harm. African Journal of Plant Science, 5, 835-841.

Akande, K., Abubakar, M., Adegbola, T., Bogoro, S. \& Doma, U. (2010). Chemical evaluation of the nutritive quality of pigeon pea [Cajanus cajan (L.) Millsp.]. International Journal of Poultry Science, 9(1), 63-65.

Arisuryanti, T., Rahmawati. \& Kartina, A. (2007). Studi kromosom jeruk nipis (Citrus aurantifolia (Chritsm.) Swingle) dan jeruk purut (Citrus hystrix DC) [The Study of the chromosomes of lime (Citrus aurantifolia (Chritsm.) Swingle) and kaffir lime (Citrus hystrix DC)]. Berkala Ilmiah Biologi, 6(2), 107-112.

Bass, H. \& Birchler, J. (2011). Plant Ctyogenetics: Genome Structure and Chromosome Function. Spring Science \& Business Media: New York.

Cooper, G. (2000). The Cell: A Molecular Approach, 2nd Edition. Sinauer Associates Sunderland (MA).

Corneillie, S., De Storme, N., Van Acker, R., Fangel, J., De Bruyne, M., De Rycke, R., Geelen, D., Willats, W.G., Vanholme, B. \& Boerjan, W. (2019). Polyploidy affects plant growth and alters cell wall composition. Plant Physiology, 179(1), 74-87.

Crow, E. \& Crow, J. (2002). 100 Years Ago: Walter sutton and the chromosome theory of heredity. Genetics, 160(1), 1-4.

Darbelley, N., Driss-Ecole, D., \& Perbal, G. (1989). Elongation and mitotic activity of cortical cells in lentil roots grown in microgravity. Plant Physiological Biochemistry, 27, 341-347.

Deeplanaiki, Ramesh, C.K., Krishna, V., Santosh, K.H.S., Dadakhalandar, D. \& Sandeep, T. (2013). Expression of drought responsive genes in pigeon pea and insilico comparison with soybean cDNA library Nagaraja. Journal of Crop Science and Biotechnology. 16(4), 243-251.

Ekanem, A. \& Osuji, J. (2006). Mitotic index studies on edible cocoyams (Xanthosoma and Colocasia spp.). African Journal of Biotechnology, 5(10), 846-849.

El-Ghamery, A., El-Nahas, A. \& Mansour, M.M. (2000). The action of atrazine herbicide as an inhibitor of cell division on chromosomes and nucleic acids content in root meristems of Allium cepa and Vicia faba. Cytologia, 65(3), 277-287.

Elrod, S. \& Stansfield, W. (2002). Genetika [Genetics]. Fourth Edditon. Erlangga: Jakarta.

Enger, E., Ross, F. \& Bailey, D. (2012). Concepts In Biology. Fourteenth Edition. McGraw-Hill: New York.

Etikawati, N. \& Setyawan, A. (2000). A cytotaxonomic study in the genus Zingiber. Biodiversitas, 1(1), 8-13.

Flower, D. \& Ludlow, M. (1987). Variation among accessions of pigeon pea (Cajanus cajan) in osmotic adjustment and dehydration tolerance of leaves. Field Crops Research, 17, 229-243.

Francis, D. (2007). The Plant Cell Cycle-15 Years On. New Phytologist, 174(2), 261-278.

Hartl, D. L. \& Jones, E. (2005). Genetics: Analysis of Genes and Genomes. 6th ed. Jones and Bartlett Publishers Inc: Massachusetts.

Iriani, N. A., Astari, D. \& Andi, S. (2020). Indeks mitosis pucuk daun Hibiscus rosa-sinensis $\mathrm{L}$. variasi single pink pada beberapa variasi waktu [The mitotic index of the leaflet of Hibiscus rosasinensis L. for single pink variation in several time variations]. Jurnal Biologi, 13(1), 1-8.

Ito, M., Araki, S., Matsunaga, S., Itoh, T., Nishihama, R., Machida, Y., Doonan, J. \& Watanabe, A. (2001). G2/M-phase-specific transcription during the plant cell cycle is mediated by c-Myb-like transcription factors. The Plant Cell, 13(8), 18911905.

Khoiroh, R., Ganies, R., Sutikno. \& Niken, S. N. (2015). Karakterisasi kromosom stroberi (Fragaria vesca L. subsp. californica Cham. \& Schltdl. cv. Californica) hasil poliploidisasi [Characterization of Strawberry Chromosomes (Fragaria vesca L. subsp. californica Cham. \& Schltdl. cv. Californica) of Poluploidiz. Biogenesis, 3(2), 87-95.

Kusumaningrum, H. P., Lunggani, A. T. \& Nurhakim, M. A. (2012). Chromosomes and mitotic cell division phase in onion roots after 24 hours acetoorcein soaking time. Bioma: Berkala Ilmiah Biologi, 14(2), 46-48.

Mathew, B., Sule, H., Toluhi, O., Idachaba, S., Ibrahim, A. \& Abuh, S. (2015). Studies on protein composition of pigeon pea [Cajanus cajan (L.) 
Millspaugh] treated with sodium azide and gamma radiation. Journal of Pharmacy and Biological Sciences, 10(1), 1-4.

Mligo, J. \& Craufurd, P. (2005). Adaptation and yield of pigeon pea in different environments in Tanzania. Field Crops Research, 94, 43-53.

Muhlisyah, M., Muthiadin, C., Wahidah, B. \& Aziz, I. (2014). Preparasi kromosom fase mitosis markisa ungu (Passiflora edulis) varietas edulis Sulawesi Selatan [Preparing chromosomes of mitotic phases of purple passion fruit (Passiflora edulis) of the variety edulis of South Sulawesi]. Biogenesis, 2(1), 48-55.

Osuji, J. \& Owei, S. (2010). Mitotic index studies on'treculia africana'decne in Nigeria. Australian Journal of Agricultural Engineering, 1(1), 25-28.

Raja, P., Kriswiyanti, E. \& Darsin, N. (2015). Indeks mitosis ujung akar kecambah cabe besar (Capsicum annuum L.) setelah perlakukan suspensi Trichoderma sp. [Mitotic index of sprout root tips of cayenne pepper (Capsicum annuum L.) after suspension treatment of Trichoderma sp.]. Jurnal Biologi, 19(2), 80-83.

Rindyastuti, R. \& Daryono, B. (2009). Identifikasi papasan (Coccinia grandis (L.) Voigt) di tiga populasi di Yogyakarta [Identifying Coccinia grandis (L.) Voigt) in three populations in Yogyakarta]. Jurnal Biologi Indonesia, 6(1), 131142.

Rosculete, C. A., Bonciu, E. \& Olaru, L. A. (2019). Determination of the environmental pollution potential of some herbicides by the assessment of cytotoxic and genotoxic effects on Allium cepa. International journal of environmental research and public health, 16(1), 75-85.

Rossato, L., Tedesco, S., Laughinghouse, H., Farias, J. \& Nicoloso, F. T. (2010). Alterations in the mitotic index of Allium cepa induced by infusions of Pluchea sagittalis submitted to three different cultivation systems. Anais Da Academia Brasileira de Ciências, 82(4), 857-860.

Saxena, K., Kumar, R. \& Gowda, C. (2010). Vegetable pigeon pea- a review. Journal of Food Legumes, 23(2), $91-98$.

Setiawan, A., Teo, C., Kikuchi, S., Sassa, H. \& Koba, T. (2018). An improved method for inducing prometaphase chromosomes in plants. Molecular Cytogenetics, 11(1), 1-8.
Setyawan, A. \& Sutikno. (2000). Karyotipe kromosom pada Allium sativum L. (bawang putih) dan Pisum sativum L. (kacang kapri) [Chromosome Karyotype in Allium sativum L. (Garlic) and Pisum sativum L. (Pea)]. BioSmart, 2(1), 20-27.

Sharma, S., Agarwal, N. \& Verma, P. (2011). Pigeon pea (Cajanus cajan L.): A hidden treasure of regime nutrition. Journal of Functional and Environmental Botany, 1(2), 91-101.

Sharma, S. \& Vig, A. . (2012). Genotoxicity of atrazine, avenoxan, diuron and quizalofop-P-ethyl herbicides using the Allium cepa root chromosomal aberration assay. Terrestrial and Aquatic Environmental Toxicology, 6(2), 90-95.

Shervani, Z. \& Mishra, P. (2020). Cytological study of Tinospora cordifolia (Willd.) Miers Ex Hook F. $\&$ Thoms. growing in four different places of hazaribag (jharkhand). Plant Archives, 20(1), 2497-2499.

Tabur, S. \& Oney, S. (2009). Effect of artificial fertilizers on mitotic index and chromosome behaviour in Vicia hybrida L. Journal of Agricultural Research, 47(1), 1-10.

Upadhyaya, H., Reddy, K., Ramachandran, S., Kumar, V., Singh, S., Reddy, T. \& Ahmed, M. (2015). Status and genetic diversity in pigeon pea germplasm from Caribbean and Central American regions at ICRISAT genebank. Plant Genetic Resources, 13(3), 01-09.

Wanjari, K., Raje, R., Durgesh, K., Prashat, G. \& Joshi, R. (2016). Pigeon pea improvement through conventional breeding. Indian Journal of Genetics and Plant Breeding, 76(4), 483-495.

Willie, P. \& Aikpokpodion, P. (2015). Mitotic activity in cowpea (Vigna unguiculata (L.) Land Race "Olaudi" Walp) in Nigeria. American Journal of Plant Sciences, 6, 1201-1205.

Yadav, P. (2007). A Textbook of Genetics. Campus Book International: New Delhi.

Yuniastuti, E., Primanita, S. \& Delfianti, M. N. (2021). Karyotypic analysis of Pigeon pea (Cajanus cajan L.). IOP Conference Series: Earth and Environmental Science, 637(1), 012094.

Zoller, J., Herrmann, R. \& Wanner, G. (2004). Chromosome condensation in mitosis and meiosis of rye (Secale cereale L.). Cytogenetic and Genome Research, 105(1), 134-144. 